\section{Corporate Financial Distress and Reorganization: A Survey of Theoretical and Empirical Contributions}

\author{
Vinicius Augusto Brunassi Silva ${ }^{1}$ \\ ${ }^{1}$ Fundação Escola de Comércio Álvares Penteado - FECAP, Sao Paulo, Brazil \\ Richard Saito ${ }^{2}$ \\ ${ }^{2}$ Getulio Vargas Foundation - FGV, EAESP, Department of \\ Accounting, Finance and Control (CFC), Sao Paulo, Brazil
}

\section{Abstract}

Purpose - This paper presents both a theoretical and empirical review of the bankruptcy and reorganization literature. We point out the main articles developed in the field and present a group of studies carried out after the approval of the new bankruptcy law in Brazil.

Design/methodology/approach - This paper provides a survey of the literature on bankruptcy and corporate reorganization. We investigate classic and recent papers in the field and present the results of some Brazilian studies that consider the announcement of the Brazilian bankruptcy law in 2005.

Findings - We show that information asymmetry, coordination problems, and heterogeneity between creditors are pivotal to the resolution of financial distress. Moreover, the choice of restructuring is made according to the least-cost alternative. We discuss the practical implications of the literature by analyzing three cases of reorganization in Brazil and reveal that the complexity of each case can drive the decision to approve or reject the reorganization plan.

Originality/value - We investigate the evolution of the bankruptcy and reorganization literature and provide a survey that explores both the international and Brazilian literature.

Keywords -bankruptcy, reorganization, corporate distress.
Received on

02/08/2019

Approved on

03/03/2020

Responsible editor:

Prof. Dr. Joelson Oliveira

Sampaio

\section{Evaluation process:}

Double Blind Review

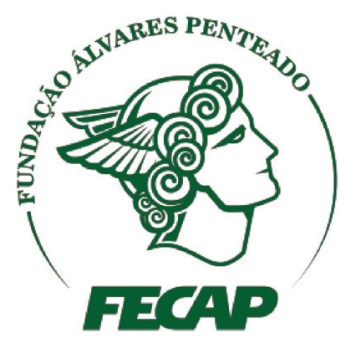

Revista Brasileira de Gestáo de Negócios 


\section{Introduction}

This paper provides both a theoretical and empirical review of bankruptcy and reorganization studies. We elaborate a general review of reorganization and bankruptcy studies, shedding light on the different issues related to the topic. We follow Senbet and Wang (2010) in showing the main issues related to bankruptcy and reorganization. Moreover, we include recent papers and show more results from Brazilian studies. This type of survey provides a broad analysis of the literature related to a specific topic. For example, Senbet and Wang (2010) undertake an extensive review of issues related to corporate financial distress and bankruptcy and Almeida, Campello, Cunha, and Weisbach (2014) provide a substantial review on corporate liquidity management.

In addition to the theoretical and empirical results presented by Senbet and Wang (2010), our paper contributes to the literature by considering recent papers in the field and by addressing research conducted in Brazil right after the announcement of the new Brazilian bankruptcy law. We also link the findings mentioned throughout our paper with three real practical cases of reorganization in Brazil. We aim to present a simple illustration of a few characteristics surrounding the reorganization decision.

In 2005, Law 11,101 took effect in Brazil in order to provide better conditions for creditors to reorganize or liquidate companies facing financial distress. The new Brazilian bankruptcy law is based on Chapter 11 of the U.S. bankruptcy code. Reorganization seems to provide a good alternative for companies in bad situations, making it possible to preserve organizational values and enabling financially distressed firms to follow growth opportunities after a failure event. In the new Brazilian bankruptcy law, firms can either restructure debt under the supervision of the bankruptcy court or attempt to restructure debt out of court (recuperação extrajudicial).
We provide a review of the empirical studies focusing on the resolution of financial distress. We first discuss papers that have estimated the direct cost of formal bankruptcy in the U.S. Next, we relate the studies that explain the characteristics of companies that have chosen a private workout. We also provide a brief review of the governance of distressed firms and the firms' outcomes after a Chapter 11 filing. Furthermore, we highlight studies conducted in Brazil after the new Brazilian bankruptcy law.

Finally, we examine the characteristics of the reorganization of three real Brazilian cases. We provide a brief description of each company, some information from the reorganization plan, and the decision from the minutes of the assembly. The data were extracted from documents of each firm facing reorganization. We analyzed the reorganization plan, the minutes of the lenders' meeting, and the list of creditors provided by the judicial trustee in charge of each case.

Our survey indicates that market frictions are critical to the reorganization decision. Information asymmetry plays an important role in creditors' demands and can enlarge coordination problems. The number of claimholders and the concentration of debt are also relevant to the outcomes of corporate financial distress. With a modest example, we show how such problems relate to practical cases of reorganizations.

The empirical papers in Brazil focus on debt reorganization, credit concession, conflict resolution, economic distress, and corporate governance. Nevertheless, researchers have not yet indicated the main drivers of success or failure in corporate reorganizations. This may be an important direction for future research.

This paper is structured as follows. The second section presents a theoretical review on reorganization and bankruptcy and highlights important empirical studies developed in the area. In addition, it presents studies that incorporate Brazilian data gathered after the new Brazilian bankruptcy law. The third section provides a case analysis of three Brazilian companies. The fourth section offers the discussion and final remarks. 


\section{Theoretical Reasons for Reorganization Choices and Bankruptcy: The RoleofAsymmetric Information, Coordination, and Cost of Restructuring}

The separation of investment and financial decisions for companies in perfect and frictionless capital markets makes bankruptcy risk irrelevant to firm value. According to Modigliani and Miller (1958, 1963), bankruptcy refers to the transfer of ownership from equity holders to other claimholders as soon as the value of assets drops below the value of debt. Hence, the value of a business entity cannot be affected by the bankruptcy costs of firms facing problems honoring promises to creditors.

However, further research demonstrates that bankruptcy costs can be crucial for firms' debt decisions. Information asymmetry, coordination problems, heterogeneity between creditors, and bankruptcy institutions play an important role in the resolution of financial distress. Kim (1978), Kraus and Litzenberger (1973), Leland (1994), and Scott (1976) show the link between bankruptcy and the existence of an optimal capital structure. Tradeoff theory presumes considerable costs related to financial distress and bankruptcy. While direct costs include court fees, lawyers, and tax accountants, indirect costs include inefficient investments and disruption among stakeholders' contracts.

The choice of debt structure influences what happens in bankruptcy according to Aghion, Hart, and Moore (1992) and Haugen and Senbet (1978). From an ex ante perspective, several studies analyze the importance of bankruptcy with respect to debtors' investments, leverage, and incentives prior to bankruptcy situations, such as those of Bebchuck (2002), Berkovitch and Israel (1999), Cornelli and Felli (1997), and Schwartz (1998), among others. These researchers shed light on the conflict between debtors and representative creditors.

Kordana and Posner (1999) expand the analysis by considering bargaining with multiple creditors. They incorporate the operation of the voting rules in Chapter 11. Moreover, Bisin and Rampini (2006), Bolton and Scharfstein (1996), Bris and Welch (2005), Hackbarth, Hennessy, and Leland (2007), Hege and Mella-Barral (2005), Thadden, Berglof, and Roland (2010), and Winton (1995) also present a multiplecreditor model considering ex ante contracting problems or an expost analysis of problems related to individual and collective liquidation rights of creditors. The studies point out that firms may face fewer problems in the future in cases where they have raised money from a single lender. Coordination problems arise in the presence of many creditors and can be extremely costly for all parties. Hence, the participation of heterogeneous creditors (and different types of debt contracts) in each firm's capital structure will make resolving financial distress more difficult.

An ex post analysis of costs related to financial distress provides an option for firms to resolve distress through formal or informal reorganization procedures. The costs of financial distress in some cases can exceed any remaining firm value; thus, companies end up being dissolved. A possible alternative is to adopt a reorganization plan that addresses the problem. Basically, the choice of restructuring is made according to the least-cost alternative. However, it is not easy to identify the choice that stakeholders view as the least expensive decision. Costs depend on the market frictions that are specific to the situation of each company. To provide a solution for distress, companies can raise money from outside investors and reorganize through debt restructuring and asset sales.

In addition to considering liquidation as an outcome, Broadie, Chernov, and Sundaresan (2007) clarify that the possibility of a court reorganization leads to conflicts of interest between borrowers and lenders. According to their first-best result, reorganization is beneficial to both stakeholders through higher debt capacity, lower credit spreads, and firm value creation.

The cost of liquidation and asset restructuring depends on the fraction of the 
assets that need to be sold and what operational relationship the liquidated assets have with those that are retained. Haugen and Senbet (1978) argue that bankruptcy costs should not be significant because claimants in financial distress should be able to negotiate out of court without affecting the underlying value of the firm. Moreover, Haugen and Senbet (1978), Jensen (1989), and Roe (1983) suggest that private reorganizations are more efficient in theory because they solve financial distress at a lower cost.

Nevertheless, some problems may appear in out-of-court cases, and costs can rise significantly. In short, resolving financial distress through private reorganization can be costlier due to holdout problems, information asymmetry, and conflicts of interest. Gilson (1997) shows that transaction costs can interfere with corporate debt reduction in cases of out-of-court reorganization.

Although a private workout can create better financial conditions for the company in distress, some creditors may choose to hold out in the restructuring process in situations where the posterior value of a claim may be higher than the value received for participating in the private reorganization. This is known as the creditor holdout problem.

In addition, the possibility of rejecting a restructuring plan, even when it is clearly advantageous for the whole company, makes resolving the financial distress a bit more difficult. Obviously, this type of problem is more likely in firms with a large number of creditors, but this is not the only condition.

The creditor holdout problem can be reduced through less stringent voting requirements, a procedure that might be achieved in court restructuring. Haugen and Senbet (1988) provide possible alternatives to eliminate the holdout problem. First, the holdout problem can be avoided when the bond trustee has the right to accept or reject tender and exchange offers on behalf of all bondholders. Second, it can be solved by making tender offers binding all holders in the same class. Third, the problem can be reduced when firms decide to put a continuous call provision on their bonds.

Asymmetric information in cases of financial distress involves disparities in the firm's value due to private information. Insiders and outsiders may have different perspectives according to their information. Hence, insiders have incentives to strategically reduce the value of all claims for claimholders during a reorganization process. Brown, James, and Mooradian (1993) and Giammarino (1989) state that asymmetric information problems can be attenuated when companies decide to enter the formal court process (facing higher costs) or choose the right securities to offer to creditors in a debt restructuring process.

Finally, conflicts of interest are quite common in restructuring situations. Cases of disparities in the distributions of wealth for different claimholders can be difficult to solve because each class of claimholder may place its own interest ahead of that of the company. For instance, junior creditors have incentives to overestimate the firm's value to obtain a higher amount of money. In contrast, senior creditors may underestimate the firm's value because they can acquire a greater portion of the firm when it continues to achieve good results. Managers can overestimate the firm's value above the liquidation value to keep their jobs. The allocation of wealth among the different classes of claimholders is a complicated bargaining process. Therefore, conflicts of interest can be extremely costly and reduce the efficiency of a reorganization. According to Brown (1989), conflicts of interest among classes increase the incentives for creditors to hold out and to engage in free riding.

Reorganizations in court provide an alternative to the problems faced in private workouts. According to Giammarino (1989), holdout and asymmetric information problems can be reduced in the case of non-unanimity voting rules, automatic stay provisions, and judicial discretion in Chapter 11. Moreover, Mooradian (1994) argues that the Chapter 11 code can be viewed as a screening device when it 
is impossible to identify the economic efficiency of the firm facing distress. Hence, inefficient firms would prefer to reorganize in court. White (1994) indicates that efficient separating and inefficient pooling equilibriums may appear under imperfect information. When efficient separating occurs, efficient firms pursue Chapter 11, while inefficient firms pursue Chapter 7. Inefficient firms tend to pursue Chapter 11 in pooling equilibriums.

Brown (1989) notes that reorganization in court helps to address conflicts of interest as well. However, the heterogeneity of creditors may still play a crucial role and create difficulties in the resolution of conflicts.

The design and structure of the bankruptcy law are important to the outcome of the reorganization process. A debtor-friendly structure permits unviable firms to reorganize and continue their business. In contrast, premature liquidation can appear in a creditor-friendly structure.

Bradley and Rosenzweig (1992) state that the U.S. bankruptcy code acts in favor of debtors so that they may retain jobs and assets. Hence, a large percentage of firms enter into reorganization processes even if the best outcome is liquidation. This problem may create several complications for firms, such as a higher cost of capital and a leverage level under the optimal point.

Baird and Ramussen (2002) and LoPucki (2003) view the issue differently, arguing that senior creditors have started to dominate courtsupervised reorganizations. According to Broadie et al. (2007), the ex post domination of creditors during restructuring is efficient because the result for debt holders is close to the firm's maximum value when it is in bankruptcy. Nevertheless, Myers (1977) shows a possibility of expropriation that benefits senior creditors in such a way that they direct the cash flow after restructuring according to their own interests.

Therefore, theoretical studies show that the least-cost alternative will drive reorganization cases. However, it depends on the level of information asymmetry and the severity of conflicts of interest and coordination problems.

\section{I Empirical studies on the resolution of financial distress}

The theoretical studies on reorganization and bankruptcy have been a source of consistent debate on the frictions and conditions that can influence firms' decisions during financial distress. The empirical studies corroborate certain results and offer additional information on how companies decide to reorganize.

For instance, Altman and Hotchkiss (2006) study different papers reporting the mean direct cost of financial distress of several cases of Chapter 11, prepackaged bankruptcies, and Chapter 7 from 1933 to 2001. They find costs from $1.4 \%$ to $9.5 \%$ of the book value of assets for Chapter 11 cases, $1.8 \%$ to $2.8 \%$ for prepackaged bankruptcies, and $6.1 \%$ to $8.1 \%$ for Chapter 7 cases. Warner (1977) provides similar evidence for 11 railroads from 1933 to 1955 in the U.S. Bris, Welch, and Zhu (2006) present the mean direct costs of 225 Chapter 11 and 61 Chapter 7 cases from 1995 to 2001. They show that Chapter 7 cases seem to present a greater downward trend than Chapter 11 cases of reorganization. On average, they find costs of $8.15 \%$ (16.9\%) for liquidation (reorganization) cases.

Furthermore, Bris et al. (2006) highlight that bankruptcy costs are very heterogeneous and seem to be sensitive to the measurement method. They claim that Chapter 7 liquidations are not cheaper than Chapter 11 reorganizations.

In terms of out-of-court restructuring, Betker (1997) and Gilson, John, and Lang (1990) report an average cost of $0.6 \%$ and $2.5 \%$, respectively, of the book value of assets from analyzing exchange offers. In addition, Chatterjee, Dhillon, and Ramirez (1995) capture the stock market reaction and show fewer negative abnormal returns related to private restructuring in comparison with Chapter 11 filings. Because of the high cost of reorganization in court, firms favor private restructuring. However, a theoretical analysis of the resolution of financial distress shows complications that hinder private restructuring and force firms to reorganize in 
court. Empirical studies indicate that a large number of companies have failed to reorganize out of court and decided to file for Chapter 11 .

An analysis of 169 financially distressed public companies was performed by Gilson et al. (1990). They find that $47 \%$ of the firms restructured their debt out of court, while 53\% of the firms had no success with this restructuring strategy and subsequently filed for Chapter 11 . Moreover, they show that private workouts are more common when firms have fewer distinct classes of debt.

Gilson et al. (1990) and Gilson, Hotchkiss, and Ruback (2000) distinguish the characteristics of the firms that solve financial distress through private workouts from those of firms that use traditional court procedures. More intangible assets, fewer lenders, and the predominance of banks explained private workouts as a choice for distressed firms. They recognize that Chapter 11 recoveries depend on how the disputes regarding a firm's value are solved. Firms that implement outof-court restructuring usually have a less complex capital structure.

Chatterjee, Dhillon, and Ramírez (1996) indicate that options for court or out-ofcourt restructuring depend on firms' liquidity, leverage, level of economic distress, and creditor coordination problems. A similar study performed by Yost (2002) notes shortcomings in the study because of the variety of sources providing the data. According to Yost (2002), performance, liquidity, capital structure, and the role of managerial discretion have an intimate connection with restructuring choices. Companies prefer to choose court restructuring in cases of information asymmetry because costs from a private workout might be higher in the presence of uncertainty. Yost (2002) investigate a third restructuring choice for companies, referred to as prepackaged bankruptcy. This type of restructuring alternative is a mix between court and private workout restructuring.

Focusing on large companies in 2002, Baird and Rasmussen (2003) calculate that one- quarter of Chapter 11 cases were prepackaged. Companies facing a greater likelihood of holdout and coordination problems should choose court reorganization. McConnel and Servaes (1991) and also Tashjian, Lease, and McConnel (1996) indicate that a prepackaged plan seems to be a tool for dealing with holdouts.

In addition, liquidity constraints can influence the decision of a company to choose a court reorganization procedure because of the automatic stay feature in Chapter 11 . Automatic stay determines that all litigation against the debtors remains in court until resolution. Performance has been considered an important driver of companies' restructuring choices because of the higher ratio of operating income to total assets in the year prior to the distress event. Gilson et al. (1990) argue that companies that belong to industries with higher median market-to-book ratios and higher ratios of operating income to total assets are more likely to restructure out of court. Yost (2002) corroborates this result.

When the sector faces difficulties, resolving distress situations can be more difficult. Creditors may put pressure on companies to liquidate assets. According to Shleifer and Vishny (1992), the likelihood of selling assets is higher when the whole industry is in distress. Moreover, Maksimovic and Phillips (1998) indicate that the likelihood of bankrupt firms selling their assets is higher in high-growth industries. Pulvino (1998, 1999) shows that industry distress can give rise to fire-sale discounts. Leverage also contributes to asset sales. Kruse (2002) and Ofek (1993) specify that the likelihood of asset sales rises when a firm's debt level is higher.

The level of financial and economic distress may influence the way creditors decide the future of a company. Hence, conflicts of interest might appear and be crucial to the outcome of the reorganization. There are conflicts among different types of creditors, stockholders, and managers. The governance of distressed companies has also been an important topic for researchers. Issues regarding management compensation and 
changes in ownership and control have received considerable attention.

Gilson (1989) analyzes 69 companies to identify the level of manager turnover in restructuring cases. Surprisingly, $71 \%$ of the managers were replaced in a period of four years. None of these managers were able to find a job in a publicly-traded company three years after they had left the company in distress. Ayotte and Morrison (2007) also find a high rate of turnover within two years of bankruptcy filings.

Owners and creditors also pay attention to the possibilities of management compensation. It is definitely important to align incentives during the reorganization period. Gilson and Vetsuypens (1993) study the contracts presented to managers during periods of distress. They capture offers to managers in charge of a reorganization before it started and those who were in charge of the company during the reorganization period. Managers that retained their position suffered a considerable cut in their salary and bonus, while new managers received $35 \%$ more in compensation than the previous manager. Hotchkiss (1995) explains that managers usually stay in charge until the moment the reorganization plan is proposed. However, they leave the company as soon as it survives the distress period.

Gilson et al. (2000) provide evidence that stock option offers occur frequently during reorganization cases. Moreover, Gilson and Vetsuypens (1993) show cases where managers receive an award once the firm has overcome a distress situation.

An interesting field of research looks at the presence of externalities in bankruptcy cases and corporate reorganizations. Benmelech and Bergman (2011) investigate how nonbankrupt competitors in U.S. airlines suffer from bankruptcies in the same industry. Based on the impact of bankruptcy on collateral values, they show that bankrupt firms reduce the collateral values of their competitors and thus increase the costs of external finance.
The consequences of choosing between liquidation and reorganization also impact the use of assets in corporate distress situations. Bernstein, Colonnelli, and Iverson (2019) check the allocation and utilization of assets in bankruptcy situations based on the random assignment of judges to liquidation and reorganization cases. They find that reorganized firms tend to use their assets more than liquidated firms, especially in thin markets. This means that liquidation can be inefficient in allocating assets under certain circumstances.

Furthermore, Bernstein, Colonnelli, Girou, and Iverson (2019) show that employment declines considerably near liquidated establishments. The spillover effect seems to be consistent with a reduction of local consumption. Benmelech, Milanez, and Mukharlyamov (2019) identify that smaller and financially distressed firms suffer more from retailer bankruptcies in cases where they are more geographically exposed.

Although the recent studies above identify causal relationships in the reorganization and bankruptcy literature, the vast majority of the studies in the field are descriptive. In addition to the papers mentioned above, other recent studies have searched for exogenous shocks to gauge causality. Hackbarth, Haselmann, and Schoenherr (2015) use the 1978 Bankruptcy Reform Act to evaluate distress risk premia when bargaining power changes from creditors to shareholders. Chakrabarti and Pattison (2019) explore the effect of an anti-cramdown provision on auto credit. The interest rates decline in the absence of cramdowns. Furthermore, they find that loan size soared among subprime borrowers.

Using another strategy to gauge causality, Campello, Gao, Qiu, and Zhang (2018) adopt a regression discontinuity design to evaluate the effect of worker unionization on bondholders in bankruptcy states. Unionizations are related to longer, costlier, and more complicated bankruptcy cases and undermine the creditor's recovery values. 


\subsection{Post-bankruptcy performance}

Some studies highlight the outcome of firms after a reorganization period. They analyze the performance of the companies a few years after their restructuring petition. LoPucki and Whitford (1993) show that a considerable portion of firms leaving the reorganization process reenter Chapter 11 a few years later.

With respect to post-bankruptcy performance, Hotchkiss (1995) finds that more than $40 \%$ of companies continued to have operating losses in the three years after reorganization. Compared to other firms in the same industry, more than $70 \%$ of the firms in reorganization showed lower performance. Eberhart, Altman, and Aggarwal (1999) show considerable positive excess stock returns for 131 companies leaving Chapter 11. Comparing their sample to a portfolio of companies in the same industry, they find an average cumulative abnormal return of 25\%. Moreover, Kalay, Singhal, and Tashjian (2007) indicate a high likelihood of efficiency gains for companies in reorganization. However, firms with more classes of debt show less improvement in performance.

Hotchkiss (1995) argues that firm size is the main determinant of a successful reorganization. The availability of divestment proposals to fund operations and pay creditors is crucial for a firm to overcome a reorganization period. Carapeto (1999) argues that a successful reorganization may heavily depend on DIP financing. In fact, Dahiya, John, Puri, and Ramirez (2003) corroborate the result by showing a higher likelihood of recovery for firms that receive DIP financing.

Most studies focus on the U.S. bankruptcy code. Nevertheless, interesting and important studies have also been developed around the world. Hotchkiss, John, Mooradian, and Thorburn (2008) analyze the international evidence and present studies from different countries, such as the United Kingdom, Sweden, France, Germany, and Japan. In addition, Senbet and Wang (2010) elaborate a survey on financial distress and bankruptcy. They review theoretical and empirical contributions to the topic and provide a discussion on comparative codes and studies in the U.S., the United Kingdom, Sweden, Germany, France, and some emerging markets, such as Brazil.

For instance, Senbet and Wang (2010) note that the old Brazilian bankruptcy law was one of the most inefficient. In fact, the old reorganization procedure only postponed corporate debt, and the resolution of cases was extremely slow. In addition, the buyer of a liquidated property usually had to assume previous debt. Reorganization under the old procedure was difficult, and many companies eventually filed for bankruptcy.

Carvalho (2005) states that the previous bankruptcy law was extremely outdated. Dating from 1945, the old bankruptcy law was perceived as a barrier to economic development. Brazil introduced a new bankruptcy law in 2005. The new law presents different means of restructuring. Moreover, firms and creditors can decide on changes in corporate control and present new terms and conditions for payments of obligations. Creditors play a more important role in reorganization cases and can vote for reorganization or liquidation. Our next section presents the empirical results of studies conducted in Brazil. We highlight papers published in economics and business journals (we do not intend to discuss any legal advancement or problem presented in law journals). We only consider results from law journals when they have a clear and direct implication for the financial conditions of the reorganization or liquidation cases.

\subsection{Corporate reorganization in Brazil: empirical evidence}

There are a variety of Brazilian studies regarding issues related to the new bankruptcy law. Brazilian Law 11,101 came into force in 2005 and improved upon the old procedure in many ways. In sum, it provides a legal framework to make it easier for firms and creditors to resolve their problems. It reduces bureaucracy and permits the options of a court-supervised or outof-court reorganization. 
There is no successor liability, and the creditor plays a more important role due to their vote on a reorganization plan. Paiva (2005) offers an explanation of bankruptcy law, providing an introduction, explanation, and analysis of the main topics related to Law 11,101, while also taking a highly qualified group of lawyers into account. Moreover, Anapolsky and Woods (2013) explain the similarities and differences between Brazilian bankruptcy law and the Chapter 11 and Chapter 7 codes. Their paper focuses on the bond market.

Some dissertations, theses, and papers have focused on different aspects and consequences of the new law. Crippa (2013), Funchal (2006), Kirschbaum (2009), Perez (2008), and Sica (2009) provide an interesting and important analysis of the specific characteristics of the reorganization process after the new Brazilian bankruptcy law. Funchal (2006) investigates the relationship between credit and bankruptcy after Law 11,101. Perez (2008) studies the critical factors of a successful recovery. Sica (2009) specifies the role and development of out-of-court reorganizations in Brazil. Kirschbaum (2009) evaluates issues regarding corporate governance, post-petition financing, and the negotiation of reorganization plans. Crippa (2013) aims to elucidate the abuse of rights during reorganization cases.

In addition, researchers have been trying to understand how companies raise money after the new Brazilian bankruptcy law with respect to both the ex-ante and ex-post reorganization period. Funchal and Clovis (2009) study the effects of the new law on a firm's level of leverage. In fact, they find an increase in the firm's level of debt after the implementation of the new law.

Monteiro and Teixeira (2009) evaluate the role of confidence during a reorganization period using qualitative research. They show that credit concessions in the reorganization period are influenced by the confidence created among debtors, managers, and creditors. Dias (2012) also analyzes cases by focusing on how distressed companies raise money in Brazil, highlighting the constitutional premises of reorganizations.

Perhaps one of the most important investigations is that of Araujo, Ferreira, and Funchal (2012), who specify a causality relationship by showing that an increase in creditor protection explains a higher level of long-term debt and a reduction in the cost of capital after a bankruptcy reform in different countries, including Brazil. Importantly, most studies in the field provide descriptive results and correlations between variables. The paper above advances the knowledge by trying to point out causal relationships.

Liu (2015) studies the determinants of financial distress in banks and shows that capital ratios, interest income, return on equity, and provisions for loan losses present a negative correlation with bank failure. Silva, Sampaio, and Gallucci (2018) examine the correlations between reorganization requests and macroeconomic variables. They find a positive (negative) relationship between the cost of capital (availability of credit) and the number of reorganizations from 2005 to 2015.

Silva and Saito (2018) evaluate the likelihood of approval of reorganization plans. They provide an empirical analysis focusing on how creditors decide to vote on reorganization plans. Their paper shows that plans with heterogeneous conditions of payment for claimholders are less likely to be accepted. The reorganization resolution depends on claimholders' rights and asset disposal seems to make the approval of reorganization plans easier.

The change in the bankruptcy law also makes it possible to identify the role of different participants in reorganizations. For instance, Moro (2011) identifies aspects of the accountant in the reorganization process. He argues that there are opportunities for improvement in the reports and analysis provided by the accountants of distressed companies.

Jupetipe, Martins, Mário, and Carvalho (2017) analyze 102 bankruptcy and 29 reorganization cases to assess the cost of each 
decision. For bankruptcy cases, they find that direct costs represent, on average, 35\% of firm assets. The initial value of the assets decreased by $47 \%$ and the creditors' money recovery rate was about $12 \%$. Reorganization cases provide average direct costs of $26 \%$ of firm assets, while the creditors' money recovery rate was about $25 \%$.

Previous studies have highlighted important issues of the bankruptcy and reorganization process that can affect debtors, creditors, managers, and other stakeholders. The next section of this paper presents three case studies on the characteristics of three companies that faced reorganization, addressing the outcome of the votes for reorganization plans analyzed in the assembly. We are interested in reorganizations filed in court.

\section{Corporate Reorganization Literature and Practical Cases in Brazil}

In this section, our goal is to elucidate the characteristics of three company restructures regarding the result of the reorganization plan presented in the assembly. In other words, we want to analyze some aspects of firms whose reorganization plans were accepted or rejected.

The previous sections suggest that lowercost alternatives drive reorganizations and liquidations. Reorganization in court seems to be a better choice when firms face market frictions that are specific to the situation of each company, such as coordination problems and conflicts of interest. Information asymmetry between stakeholders makes the reorganization process harder. Firms seeking out-of-court restructuring usually have fewer lenders and a less complex capital structure.

It is interesting to analyze the complexity of the recovery process through the outcome of some real cases. For instance, Penati and Zingales (1997) analyze the case of the Ferruzzi Group, one of the largest out-of-court restructurings in history. The study sheds light on the efficiency and distributional consequences of the reorganization.
It provides a good example of how lender heterogeneity and conflicts of interests can drive the reorganization process. In addition, Weiss and Wruck (1998) explain the conflicts of interest between the shareholders and manager in the Eastern Airlines bankruptcy case and Noe and Rebello (2003) evaluate Macy's bankruptcy, focusing on the conflicts of interest among stakeholders. We elaborate a similar analysis for some firms in Brazil.

As expected, the cases are extremely heterogeneous with respect to the number of creditors, participation of banks, amount of debt, and reorganizing actions. One of the largest reorganization cases in Brazil took place in September 2016. Oi, one of the largest mobile companies in the country, had to renegotiate more than BRL 64 billion with approximately 55,000 lenders. It took more than a year to approve the reorganization plan at the creditors' meeting. We did not study this case because all the reorganization files were not yet complete.

We focus on three other cases involving different levels of complexity that may be pivotal to the reorganization outcome. The complexity of each case is different and may explain the decision to approve or reject the reorganization plan. We analyze three very different companies in various dimensions, such as size, number of lenders, class of lenders (according to the level of collateral), and amount of debt. Hence, each case presents different magnitudes of coordination problems and conflicts of interest. We aim to present a simple example of the existence of the situations indicated by the literature in reorganization cases in Brazil.

The information in our analysis is taken from the reorganization plan, the minutes of the general meeting, and the list of creditors, with claims provided by each company. Private and small companies account for an overwhelming number of reorganization cases in Brazil. Hence, we also decided to study cases involving private companies instead of only publicly-traded ones. First we analyze the Bical case, then we study the 
case of NTL-MD8, and we finish our analysis with that of the $\mathrm{X}$ group.

Bical - Birigui Calçados Ind. e Com. Ltda was founded in 1965 in the state of Sao Paulo. The head office is located in Sao Paulo, and it has two more branches, one in Sao Paulo and the other in Mato Grosso do Sul. For more than 40 years the company has focused its operations on manufacturing and commercializing shoes in local and external markets.

The firm filed for reorganization in October of 2011. The main reasons for distress were as follows: i) the 2008 crisis caused considerable losses due to the reduction in sales in external markets; ii) difficulties competing against the prices of Chinese companies; iii) a considerable portion of workers decided to move to other sectors; iv) an increase in debt to finance working capital needs; and v) the exacerbated cost of capital to finance its activities. The company also noted an overall reduction in industrial production as an explanation for its bad results.

The firm only has labor and unsecured creditors. The amount of debt in reorganization equals BRL 16,361,367.85. The percentage of debt in the hands of banks is approximately $70 \%$ of the total unsecured debt. However, the quantity of banks with claims in the unsecured class is less than $3 \%$.

In the reorganization plan, the company promises to save part of its sales to pay secured and unsecured creditors. Although the reorganization plan clarifies the strategy for payment to secured creditors and presents the amount of debt to be paid to that class, there is no secured creditor specified in the list of creditors provided by the judicial trustee. The minutes of the assembly confirm that only labor and unsecured classes voted on the plan.

The literature points out that a reorganization plan is more easily accepted in the presence of fewer creditor and claimholder classes. More variables related to the reorganization plan can certainly attenuate any possibility of failure (grace period, payment period, reduction in the amount of debt, asset sales, cash flow forecasting, and others). Nevertheless, it is noted that firms with the same reorganization features but fewer coordination problems between creditors face a greater chance of reorganization.

Moving on to the next case, the companies NTL Têxtil Ltda and MD8 Têxtil Ltda were founded in 1989 in Sao Paulo. Although they are separate companies, they asked for joint treatment when filing for reorganization due to the large number of creditors they had in common. Thus, we will treat them as NTLMD8. The textile company made products from polypropylene, polyester, and cotton. The firm filed for reorganization in October of 2008. The main reasons were as follows: i) NTL-MD8 blames a competitor for practicing dumping as soon as the firm decided to open a new branch in Mato Grosso do Sul; ii) the textile industry is facing constant modifications, and massive investment in technology is important; and iii) the sector is extremely dependent on internal capital to finance its projects.

In response to the distress problem, the firm decided to implement several measures. It reduced its workforce considerably, enforced more severe cost control measures, decided to make purchases by paying in advance, and engaged in strategies to increase sales. The reorganization plan clarifies that NTL aims to incorporate MD8; thus, it was considered a single reorganization of both companies.

The general meeting took place on April 17th, 2009. All creditors rejected the plan. After the presentation of the reorganization plan by the debtor, some modifications were proposed. For instance, there was a new specification proposing full payment of creditors with claims equal to or less than BRL 10,000. The labor debt was to be paid in three sequential installments. There was also the exclusion of MD8's incorporation by NTL. In one more round of votes, all labor and $78.17 \%$ of unsecured creditors approved the plan. However, the secured class of claimholders rejected the plan. According to the minutes of the 
assembly, only one secured creditor voted for the plan (Banco do Brasil). Hence, the plan was not approved by all classes of creditors.

This case sheds light on how the concentration of power can drive the reorganization result. Because senior creditors may have incentives to reject the plan and receive their claims, extreme concentration in the hands of secured creditors was the determinant of the outcome of the plan.

Finally, we present the case of a large publicly-traded company in Brazil. The companies of the $\mathrm{X}$ group that are in financial distress are OGX Petróleo e Gás S.A, OGX Austria GmbH, and Óleo e Gás Participaçóes (OGPar). The reorganization of this group has received considerable attention in Brazil. In short, OGX is a company that explores, refines, processes, trades, and transports oil (among other activities). Since 2007 , the X group has been exploiting oil in the Campos, Santos, Espírito Santo, Parnaíba, and Pará-Maranhão basins. As a majority shareholder, Eike Batista was in charge of the group. The information provided below is the same for all the reorganizing companies of the group.

OGX raised money by issuing bonds (2018 bonds and 2022 bonds) to finance its projects. The reorganization plan reveals that more than 3 billion dollars were raised. The group filed for reorganization in October of 2013. The main reasons for distress were as follows: i) risks related to group activities such as oil exploration. The exploration of some locations was considered impractical; ii) the default of Petronas Brasil E\&P led to severe difficulties.

To solve its financial problems, the group decided to obtain new funding. Hence, the group resorted to DIP (the issuance of corporate bonds) and additional financing specifying some assets as collateral. The issuance of corporate bonds would occur in three tranches of 125, 90, and 90 million dollars, respectively.

The money was to be invested in projects and working capital activities. Moreover, the reorganization plan indicates that payment to financial claimholders of the bonds in 2018 and 2022 will be done through the capitalization of credit. In sum, the group pursued an increase in capital through the capitalization of credit and converting corporate bonds. Non-financial unsecured creditors will be paid in 48 monthly fixed tranches of the same value. The group has no claims from labor or secured creditors.

The reorganization plan shows that, after the incorporation, stocks were traded as $O G X$ Reestruturada. Due to the incorporation, the ownership of stockholders in OGX Reestruturada is as follows: i) creditors financing the first tranche of corporate bonds own $41.9767 \%$; ii) actual or new out-of-reorganization creditors who accept the plan own 25\%; iii) creditors financing the second and third tranches of corporate bonds own $23.0233 \%$; iv) a few asset funds own $5.02 \%$; v) other stockholders from OGPar own $4.98 \%$; and vi) Eike Batista owns 1 stock.

Moreover, the reorganization plan shows the existence of warrants for stockholders presenting the following conditions: i) 1.5 billion dollars; ii) five years of maturity; iii) the number of common shares to be subscribed must equal $15 \%$ of the stocks from OGX Reestruturada; and iv) the values will be corrected by an inflation index $(I G P-M)$.

The company can divest assets, and the conditions specified in the reorganization plan are respected. In addition, the reorganization plan presents to OGPar the option to file for Chapter 15 bankruptcy if it is determined as necessary.

The first $\mathrm{X}$ group general meeting happened on June 3rd, 2014. The quorum was approximately $62.79 \%$ of unsecured creditors, the only class able to vote on the plan. As soon as claimholders were able to express their concerns in the meeting, one creditor asked the debtor about the number of expenses not subject to the reorganization plan. The debtor answered that only one new creditor had joined the plan. It was specified that after debt conversion, equity would be close to BRL 3.3 billion and debt would be close to BRL 200 million. The creditors 
of the second tranche of corporate bonds were informed that they were entitled to subscribe for the remaining third tranche if there was not full subscription from the third tranche's creditors.

After a brief discussion of the proposals related to the third tranche of corporate bonds, with subsequent rejection of the proposals by the debtor, the plan was voted on. According to the minutes of the assembly, $81.59 \%$ of claimholders approved the reorganization plan (the value represents $90.42 \%$ ). The number of abstentions was five. Hence, the plan was considered approved.

This last case shows how access to external finance can help solve distress problems. Moreover, it specifies that the concentration of claims for creditors with the same position of seniority might attenuate conflicts and lead to the rejection of the plan.

Interesting differences among the cases can be observed. The first one is the number of classes that vote on the plan in each case. There are two classes of creditors for Bical (labor and unsecured), three classes for NTL-MD8, and only one for the $\mathrm{X}$ group. It is possible that companies with three classes of creditors present more complexity, and therefore it is more difficult to have the reorganization plan approved. For instance, the plan for NTL-MD8 was approved by labor and unsecured creditors and rejected by secured creditors. It seems to be more difficult to align incentives and present a more homogeneous proposal to creditors in cases like this. Creditors grouped in different classes have different incentives. In Brazil, Silva and Saito (2018) show that heterogeneous payment to creditors is related to a lower approval rate of reorganization plans. They mention that secured debt creditors have lower incentives to approve reorganizations. The secured debt class receives right after the labor debt creditors in cases of liquidation and usually prefers to liquidate a portion of the assets to receive cash.

It is also worthwhile paying attention to the concentration of value among creditors. In the case of Bical, there is a huge concentration of value in the hands of a few banks. The concentration of NTL-MD8 and the X group was somewhat more spread out. It is possible that less concentration of money makes it more difficult for creditors and debtors to come to an agreement. Ivashina, Iverson, and Smith (2016) explain that the concentration of claims in one specific class of creditors is important to attenuate coordination problems.

The extreme concentration of value in the hands of a few creditors in the same class can also influence the type of reorganization plan that is decided upon. For instance, NTL-MD8 had only one secured creditor who rejected the plan. In such a case, the debtor must meet all the demands of creditors (if that is possible). Otherwise, the plan will be rejected. Cai (2000) shows that reorganization is easier and more efficient when the number of creditors is small.

Finally, access to external funding is necessary to solve the financial distress problem. The $\mathrm{X}$ group was able to present a strategy that is based on external funding. The group presented a proposal with a severe modification to the composition of ownership. The option of obtaining additional funding seemed to be crucial to the group.

It is also interesting that in no case did all creditors vote on the plan. Regardless of the number of classes, a considerable amount of absenteeism was registered in the minutes of the assembly. Moreover, two of the three cases presented a quorum delay in the first general meeting, and the plan vote was postponed.

\section{Final Remarks}

In this paper, we explore theoretical and empirical contributions to the bankruptcy and reorganization literature. The theoretical papers point out problems of information asymmetry, coordination, conflicts of interest, and settlement costs as pivotal aspects surrounding distress resolution. From an ex-ante perspective, some studies propose that less complex capital structures favor the resolution of future debt problems. 
In addition, some researchers indicate that a higher concentration of claims among fewer creditors is beneficial to reduce creditor coordination and holdout problems. Our real case examples show a simple picture considering practical applications of such a scenario. The company Bical presented a considerable concentration of money in the hands of a few banks (and also only two classes of creditors), while NTL-MD8 was somewhat more spread out. According to Annabi, Breton, and Français (2012), the bargaining between creditors is considered a non-cooperative game. Fan and Sundaresan (2000) mention that these cases are more aligned to a larger-scale prisoner's dilemma.

The empirical studies highlight reorganization decisions. They explore the theoretical literature to explain the main determinants of a corporate reorganization. For example, court or out-of-court choices are related to firms' liquidity, leverage, level of economic distress, and creditor coordination problems.

The least-cost alternative will guide the reorganization decision. However, costs are highly related to market frictions and each firm can face potentially different situations. Firms prefer outof-court reorganizations in the absence of severe coordination problems. Court reorganization would be preferable in cases of information asymmetry and considerable conflicts of interest.

In addition, the resolution of financial distress depends on several variables and the situation can be more tragic in the presence of economic distress. When the whole sector (or the entire economy) is experiencing adversity, the difficulty of generating cash increases and the likelihood of selling assets to obtain some cash is even higher. Maksimovic and Phillips (1998) and Pulvino $(1998,1999)$ clarify that economic distress gives rise to fire-sale discounts. In Brazil, Silva, Sampaio, and Gallucci (2018) show that adverse economic conditions are related to more requests for court reorganizations.

The remaining empirical literature also analyzes issues related to management compensation, manager turnover, and postreorganization performance. Basically, the studies in Brazil have evaluated issues related to debt reorganization, credit concession, conflict resolution, and corporate governance.

The research on reorganization and bankruptcy has not presented any meaningful empirical investigations on out-of-court reorganizations, management compensation, and post-reorganization performance. In part, this is because data are not easily available. In addition, we have not had a large number of out-of-court reorganizations in Brazil (we have just a few cases of public firms and less than 200 cases since our new bankruptcy law). Moreover, firms usually prepare their reorganization plans considering more than ten years to exit reorganization status. Hence, post-reorganization performance is still a topic to be investigated in Brazil.

Future research can explore the determinants of success and failure of companies that have emerged from reorganizations (both in court and out of court). Papers that explore exogenous variations and indicate causal effects will also be extremely important, as the vast literature in the field is essentially descriptive.

\section{References}

Aghion, P., Hart, O., \& Moore, J. (1992). The economics of bankruptcy reform. Journal of Law, Economics, \& Organization, 8(3), 523-546.

Almeida, H., Campello, M., Cunha, I., \&Weisbach, M. S. (2014.) Corporate liquidity management: A conceptual framework and Survey. Annual Review of Financial Economics 6, 132-145. Retrieved from https://www.annualreviews.org/doi/abs/10.1146/ annurev-financial-1 10613-034502

Altman, E. I., \& Hotchkiss, E. (2006). Corporate financial distress and bankruptcy (3rd ed.). Hoboken, New Jersey: John Wiley \& Sons.

Annabi, A., Breton, M., \& François, P. (2012). Resolution of financial distress under chapter 
11. Journal of Economic Dynamics and Control, 36(12), 1867-1887. https://doi.org/10.1016/j. jedc.2012.06.004

Anapolsky, J. M., \& Woods, J. F. (2013). Pitfalls in Brazilian bankruptcy law for international bond investors. Journal of Business e Technology Law, 8(2), 397-450.

Araujo, A. P., Ferreira, R.V.X., \& Funchal, B. (2012). The Brazilian bankruptcy law experience. Journal of Corporate Finance. 18(4), 994-1004.

Ayotte, K. M., \& Morrison, E. R. (2007). Creditor control and conflict in chapter 11. (Working Paper No. 321). Retrieved from https://papers.ssrn. com/sol3/papers.cfm?abstract_id=1081661

Baird, D. G., \& Rasmussen, R. K. (2002). The end of bankruptcy. Stanford Law Review 55(2), 751-789.

Baird, D. G., \& Rasmussen, R.K. (2003). Chapter 11 at Twilight. Stanford Law Review, 56(3), 673699.

Bebchuck, L. A. (2002). Ex ante costs of violating absolute priority in bankruptcy. Journal of Finance (Wiley-Blackwell), 7(1), 445-460.

Benmelech, E., \& Bergman, N. (2011). Bankruptcy and the collateral channel. The Journal of Finance, 66(2), 337-378.

Benmelech, E., Bergman, N., Milanez, A., \& Mukharlyamov, V. (2019). The agglomeration of bankruptcy. The Review of Financial Studies, 32(7), 2541-2586.

Berkovitch, E., \& Israel, R. (1999). Optimal bankruptcy laws across different economic systems. The Review of Financial Studies, 12(2), 347-377.

Bernstein, S., Colonnelli, E., Giroud, X., \& Iverson, B. (2019). Bankruptcy spillovers. Journal of Financial Economics, 133(3), 608-633.
Bernstein, S., Colonnelli, E., \& Iverson, B. (2019). Asset allocation in bankruptcy. The Journal of Finance, 74(1), 5-53.

Betker, B. L. (1997). The administrative cost of debt restructurings: Some recent evidence. The Journal of the Financial Management, 26(4), 5668.

Bisin, A., \& Rampini, A. A. (2006). Exclusive contracts and the institution of bankruptcy. Economic Theory 27(2), 277-304.

Bolton, P., \& Scharfstein, D. S. (1996). Optimal debt structure with multiple creditors. Journal of Political Economy 104(1), 1-25.

Bradley, M., \& Rosenzweig, M. (1992). The untenable case for chapter 11. The Yale Law Journal 101(5), 1043-1095.

Bris, A., \& Welch, I. (2005). The optimal concentration of creditors. Journal of Finance 60(5), 2193-212.

Bris, A., Welch, I., \& Zhu, N. (2006). The costs of bankruptcy: Chapter 7 liquidation versus chapter 11 reorganization. Journal of Finance, 61(3), 1253-1303.

Broadie, M., Chernov, M., \& Sundaresan, S. (2007). Optimal debt and equity values in the presence of chapter 7 and chapter 11. Journal of Finance, 62(3), 1341-1377.

Brown, D. T. (1989). Claimholder incentive conflicts in reorganization: The role of bankruptcy law. Review of Financial Studies, 2(1), 109-123.

Brown, D. T., James, C. M., \& Mooradian, R. M. (1993). The information content of distressed restructurings involving public and private debt claims. Journal of Financial Economics 33(1), 93-118.

Cai, H. (2000). Delay in multilateral bargaining under complete information. Journal of Economic Theory, 93(2), 260-276. 
Campello, M., Gao, J., Qiu, J., \& Zhang, Y. (2018). Bankruptcy and the cost of organized labor: Evidence from union elections. The Review of Financial Studies, 31(3), 980-1013.

Carapeto, M. (1999). Does debtor-in-possession add value? (IFA Working Paper No. 294-1999). Retrieved from https://papers.ssrn.com/sol3/ papers.cfm?abstract_id $=161428$

Carvalho, A. G. de (2005). Lei de Falência, acesso ao crédito empresarial e taxas de juros no Brasil. Revista de Economia Politica = Brazilian Journal of Political Economy, 25(1), 131-153.

Chakrabarti, R., \& Pattison, N. (2019). Auto credit and the 2005 bankruptcy reform: The impact of eliminating cramdowns. The Review of Financial Studies, 32(12), 4734-4766.

Chatterjee, S., Dhillon, U. S., \& Ramirez, G. G. (1995). Coercive tender and exchange offers in distressed high-yield debt restructurings: An empirical analysis. Journal of Financial Economics, 38(3), 333-360.

Chatterjee, S., Dhillon, U. S., \& Ramírez, G. G. (1996). Resolution of financial distress: Debt restructurings via chapter 11 , prepackaged bankruptcies, and workouts. Financial Management Association, 25(1), 5-18.

Cornelli, F., \& Felli, L. (1997). Ex-ante efficiency of bankruptcy procedures. European Economic Review 41(3), 475-485.

Crippa, C. S. de V. (2013). O Abuso do direito na recuperação judicial (Dissertação de Mestrado). Pontifícia Universidade Católica de São Paulo - PUC, São Paulo, SP, Brasil. Retrieved from https://tede2.pucsp.br/handle/handle/6200

Dahiya, S., John, K., Puri, M. \& Ramirez, G. (2003). The dynamics of debtor-in-possession financing: Bankruptcy resolution and the role of prior lenders. Journal of Financial Economics 69, 259-280.
Dias, L. A. R. (2012). Financiamento das empresas em crise (Dissertação de Mestrado). Faculdade de Direito da Universidade de Sáo Paulo - USP, São Paulo, SP, Brasil. Retrieved from https:// www.teses.usp.br/teses/disponiveis/2/2132/tde27082013-114525/pt-br.php

Eberhart, A. C., Altman, E. I., \& Aggarwal, R. (1999). The equity performance of firms emerging from bankruptcy. Journal of Finance, 54(5), 1855-1868.

Fan, H., \& Sundaresan, S. M. (2000). Debt valuation, renegotiation, and optimal dividend policy. Review of Financial Studies, 13(4), 10571099. https://doi.org/10.1093/rfs/13.4.1057

Funchal, B. (2006). Essays on credit and bankruptcy law (Doctoral Thesis). Fundação Getúlio Vargas - FGV, Rio de Janeiro, RJ, Brasil.

Funchal, B., Clovis, M. (2009). Firm's capital structure and bankruptcy law design. Journal of Financial Economic Policy. 1(3), 264-275. doi: $10.1108 / 17576380911041737$.

Giammarino, R. M. (1989). The resolution of financial distress. The Review of Financial Studies, 2(1), 25-47.

Gilson, S. C. (1989). Management turnover and financial distress. Journal of Financial Economics 25(2), 241-262.

Gilson, S. C. (1997). Transactions costs and capital structure choice: Evidence from financially distressed firms. The Journal of Finance, 52(1), 161-196.

Gilson, S. C., Hotchkiss, E. S., \& Ruback, R. S. (2000). Valuation of bankrupt firms. The Review Financial Studies, 13(1), 43-74.

Gilson, S. C., John, K. \& Lang, L. H. P. (1990). Troubled debt restructurings: An empirical study of private reorganization of firms in default. Journal of Financial Economics, 27(2), 315-353. 
Gilson, S. C., \& Vetsuypens, M. R. (1993). CEO compensation in financially distressed firms: An empirical analysis. Journal of Finance 48(2), 425-458.

Hackbarth, D., Haselmann, R., Schoenherr, D. (2015). Financial distress, stock returns, and the 1978 bankruptcy reform act. Review of Financial Studies, 28(6), 1810-1847.

Hackbarth, D., Hennessy, C. A., \& Leland, H. E. (2007). Can the tradeoff theory explain debt structure? The Review of Financial Studies, 20(5), 1389-428.

Haugen, Robert A., \& Senbet, L. W. (1978). The insignificance of bankruptcy costs to the theory of optimal capital structure. Journal of Finance, 33(2), 383-392.

Haugen, Robert A., \& Senbet, L. W. (1988). Bankruptcy and agency costs: Their significance to the theory of optimal capital structure. Journal of Financial and Quantitative Analysis, 23(1), 27-38.

Hege, U., \& Mella-Barral, P. (2005). Repeated dilution of diffusely held debt. The Journal of Business, 78(3), 737-786.

Hotchkiss, E. S. (1995). Postbankruptcy performance and management turnover. The Journal of Finance, 50(1), 3-21.

Hotchkiss, E. S., John, K., Mooradian, R. M., \& Thorburn K. S. (2008). Bankruptcy and the resolution of financial distress. In B. E. Eckbo (Ed.), Handbook of Empirical Corporate Finance (Vol. 2, Chap.14, pp. 235-287). North Holland: Elsevier.

Ivashina, V., Iverson, B., Smith, D.C. (2016). The ownership and trading of debt claims in chapter 11 restructurings. Journal of Financial Economics, 119(2), 316-335.

Jensen, M. C. (1989). Active investors, LBOs, and the privatization of bankruptcy. Journal of Applied Corporate Finance, 2(1), 35-44.
Jupetipe, F. K. N., Martins, E., Mário, P. do C., \& Carvalho, L. N. G. de (2017). Custos de falência no Brasil comparativamente aos estudos norteamericanos. Revista Direito GV, 13(1), 20-48.

Kalay, A., Sighal, R., \& Tashjian, E. (2007). Is Chapter 11 costly? Journal of Financial Economics, 84(3), 772-796.

Kim, E. H. (1978). A mean-variance theory of optimal capital structure and corporate debt capacity. The Journal of Finance, 33(1), 45-64.

Kordana, K. A., \& Posner, E. (1999). A positive theory of chapter 11. New York University Law Review, 74(1), 161-234.

Kraus, A., \& Litzenberger, R. H. (1973). A statepreference model of optimal financial leverage. The Journal of Finance, 28(4), 911-922.

Kruse, T. A. (2002). Asset liquidity and determinants of asset sales by poorly performing firms. Financial Management, 31(4), $107-$ 129.

Leland, H. E. (1994). Corporate debt value, bond covenants, and optimal capital structure. The Journal of Finance, 49(4), 1213-1252.

LoPucki, L. M. (2003). The nature of the bankrupt firm: A response to Baird and Rasmussen's the end of bankruptcy. Stanford Law Review, 56(3), 645-671.

Liu, Z. J. (2015). Cross-Country study on the determinants of bank financial distress. RAE: Revista de Administração, 55(5), 593-603.

LoPucki, L. M., \& Whitford, W. C. (1993). Patterns in bankruptcy reorganization of large, publicly held companies. Cornell Law Review, 78(4), $597-618$.

Kirschbaum, D. (2009). A recuperação judicial no Brasil: Governança, financiamento extraconcursal e votação do plano (Tese de Doutorado). Faculdade de Direito da Universidade de São Paulo - USP, 
São Paulo, SP, Brasil. Retrieved from https:// www.teses.usp.br/teses/disponiveis/2/2132/tde03062011-104905/pt-br.php

Maksimovic, V., \& Phillips, G. (1998). Asset efficiency and reallocation decisions of bankrupt firms. Journal of Finance 53(5), 1495-1532.

McConnell, J. J., \& Servaes, H. (1991). The economics of pre-packaged bankruptcy. Journal of Applied Corporate Finance 4(2), 93-98.

Modigliani, F., \& Miller, M. H. (1958). The cost of capital, corporation finance, and the theory of investment. The American Economic Review, 48(3), 261-275.

Modigliani, F., \& Miller, M. H. (1963). Corporate income taxes and the cost of capital: A correction. The American Economic Review, 53(3), 433-443.

Monteiro, R. S., \& Teixeira, M. L. M. (2009). O Papel da confiança na concessão de crédito para empresas em recuperação. Revista de Administração Mackenzie, 10(1), 1678-6971.

Mooradian, R. M. (1994). The effect of bankruptcy protection on investment: Chapter 11 as a screening device. Journal of Finance, 49(4), 1403-1430.

Moro, S., Jr. (2011). A Contabilidade nos processos de recuperação judicial: Análise na comarca de São Paulo (Dissertação de Mestrado). Fundação Escola de Comércio Álvares Penteado - FECAP, São Paulo, SP, Brasil.

Myers, S. (1977). Determinants of corporate borrowing. Journal of Financial Economics, 5(2), 147-175.

Noe, T. H, \& Rebello, M. J. (2003). Reputation and the market for distressed-firm debt. Journal of Financial \& Quantitative Analysis, 38(3), 503-521.

Ofek, E. (1993). Capital structure and firm response to poor performance. Journal of Financial Economics, 34(1), 3-30.
Paiva, L. F. V. (Coord.). (2005). Direito falimentar e a nova lei de falências e recuperação de empresas. São Paulo: Quartier Latin.

Penati, A., \& Zingales, L. (1997). Efficiency and distribution in financial restructuring: The case of Ferruzi Group (CRSP Working Paper No. 466). Retrieved from https://papers.ssrn.com/sol3/ papers.cfm?abstract_id=224439

Perez, M. M. (2008). Uma contribuição ao estudo do processo de recuperação de empresas em dificuldades financeiras no Brasil (Tese de Doutorado). Faculdade de Economia, Administração e Contabilidade da Universidade de São Paulo, SP, Brasil. Retrieved from https://teses.usp.br/teses/ disponiveis/12/12139/tde-02092008-155403/ pt-br.php

Pulvino, T. C. (1998). Do asset fire-sales exist? An empirical investigation of commercial aircraft transactions. Journal of Finance 53(3), 939-978.

Pulvino, T. C. (1999). Effects of bankruptcy court protection on asset sales. Journal of Financial Economics, 52(2), 151-186.

Roe, M. J. (1983). Bankruptcy and debt: A new model for corporate reorganization. Columbia Law Review, 83(3), 527-602.

Schwartz, A. (1998). A contract theory approach to business bankruptcy. Yale Law Journal, 107(6), 1806-51.

Scott, J. H., Jr. (1976). A theory of optimal capital structure. Bell Journal of Economics, 7(1), 33-54.

Senbet, L. W., \& Wang, T. Y. (2010). Corporate financial distress and bankruptcy: A survey. Foundations and Trends in Finance 5(4), 243-335. doi:10.1561/0500000009.

Shleifer, A., \& Vishny, R. W. (1992). Liquidation values and debt capacity: A market equilibrium approach. Journal of Finance, 47(4), 1343-1366. 
Sica, L. P. P. P. (2009). Recuperação extrajudicial de empresas: Desenvolvimento do direito de recuperação de empresas brasileiro (Tese de Doutorado). Faculdade de Direito da Universidade de São Paulo, São Paulo, SP, Brasil.

Silva, V. A. B., \& Saito, R. (2018). Corporate restructuring: Empirical evidence on the approval of the reorganization plan. RAUSP Management Journal, 53(1), 49-62.

Silva, V. A. B., Sampaio, J. O., \& Gallucci, H., Neto (2018). Pedidos de recuperação judicial no Brasil: Uma explicação com variáveis econômicas. Revista Brasileira de Finanças, 16(3), 429-454.

Tashjian, E., Lease, R. C., \& McConnell, J, J. (1996). Prepacks: An empirical analysis of prepackaged bankruptcies. Journal of Financial Economics, 40(1), 135-162.

Thadden, E. L. von, Berglof, E., \& Roland, G. (2010). The design of corporate debt structure and bankruptcy. Review of Financial Studies, 23(7), 2648-2679.
Warner, J. B. (1977). Bankruptcy costs: Some evidence. The Journal of Finance 32(2), 337-347.

Weiss, L. A., \&, Wruck, K. H. (1998). Information problems, conflicts of interest, and asset stripping: Chapter 11's failure in the case of Eastern Airlines. Journal of Financial Economics, 48(1), 55-97.

White, M. J. (1994). Corporate bankruptcy as a filtering device: Chapter 11 reorganizations and out-of-court debt restructurings. Journal of Law, Economics, \& Organization, 10(2), 268-295.

Winton, A. (1995). Costly state verification and multiple investors: The role of seniority. Review of Financial Studies, 8(1), 91-123.

Yost, K. E. (2002, September). The choice among traditional Chapter 11, prepackaged bankruptcy and out-of-court restructuring. [Working paper]. School of Business University of Wisconsin, Madison. Retrieved from http://www.textbiz.org/ projects/defaultprediction/yost_paper.pdf 


\section{Authors:}

1. Vinicius Augusto Brunassi Silva, Doctor in Business Administration (Finance), FGV, Sao Paulo, Brazil. E-mail: vinicius.brunassi@fecap.br

ORCID

(iD) 0000-0002-1299-321X

2. Richard Saito, PhD in Engineering-Economic Systems, Stanford University, California, USA. E-mail: rsaito@finenge.com

ORCID

(iD) 0000-0002-9512-9071

\section{Contribution of each author}

\begin{tabular}{lcc}
\hline Contribution & Vinicius Brunassi & Richard Saito \\
\hline 1. Definition of research problem & $\sqrt{ }$ & $\sqrt{ }$ \\
2. Development of hypotheses or research questions ( empirical studies ) & $\sqrt{ }$ \\
3. Development of theoretical propositions ( theoretical work) & $\sqrt{ }$ \\
4. Theoretical foundation/ Literature review & $\sqrt{ }$ \\
5. Definition of methodological procedures & $\sqrt{ }$ \\
6. Data collection & $\sqrt{ }$ \\
7. Statistical analysis & $\sqrt{ }$ \\
8. Analysis and interpretation of data & \\
9. Critical revision of the manuscript & \\
10. Manuscript writing & \\
11. Other (please specify which) & \\
\hline
\end{tabular}

